\title{
Simultaneous native nephrectomy with renal transplantation: Our experience and a brief literature review
}

\author{
Renal transplantasyonla eș zamanlı nativ nefrektomi: Deneyimlerimiz ve kısa bir literatür \\ derlemesi
}

\author{
Serdar Karadağ', Ahmet Faysal Güler', Taner Kargı', Ahmet Hacıislamoğlu', Hakan Polat', İsmail Evren', Mithat Ekşi², \\ Deniz Noyan Özlü', Osman Özdemir ${ }^{1}$ \\ 1 University of Health Sciences, Bakırköy Dr. Sadi Konuk Training and Research Hospital, Department of Urology, Istanbul, Turkey \\ 2 Arnavutköy State Hospital, Department of Urology, Istanbul, Turkey
}

\begin{tabular}{|c|c|}
\hline \multicolumn{2}{|c|}{ 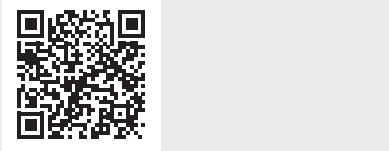 } \\
\hline \multicolumn{2}{|c|}{ Submitted (Geliş tarihi): 2021-06-10 } \\
\hline \multicolumn{2}{|c|}{ Accepted (Kabul tarihi): 2021-10-18 } \\
\hline \multicolumn{2}{|c|}{ Correspondence / Yazışma } \\
\hline \multicolumn{2}{|c|}{ Deniz Noyan Özlü } \\
\hline \multicolumn{2}{|c|}{ Zuhuratbaba Mah. Dr. Tevfik Sağlam St. } \\
\hline \multicolumn{2}{|c|}{ No:11, 34147, Bakırköy / İstanbul } \\
\hline \multicolumn{2}{|c|}{ Email:noyanozlu@hotmail.com } \\
\hline \multicolumn{2}{|c|}{ Tel: +90 5352336440} \\
\hline \multicolumn{2}{|c|}{ Fax: +90 2124147280} \\
\hline \multicolumn{2}{|c|}{ ORCID } \\
\hline S.K. & 0000-0002-1420-4536 \\
\hline A.F.G. & 0000-0003-0320-7843 \\
\hline Г.К. & 0000-0001-5874-3489 \\
\hline A.H. & 0000-0002-6117-2098 \\
\hline H.P. & $0000-0003-1525-1243$ \\
\hline E. & 0000-0003-4008-8038 \\
\hline M.E. & 0000-0003-1490-3756 \\
\hline D.N.Ö. & $0000-0003-2435-5482$ \\
\hline O.Ö. & 0000-0003-0375-8282 \\
\hline \multicolumn{2}{|c|}{ 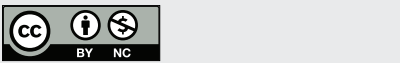 } \\
\hline \multicolumn{2}{|c|}{ This work is licensed under a Creative } \\
\hline $\begin{array}{l}\text { Commo } \\
4.0 \text { Inter }\end{array}$ & $\begin{array}{l}\text { tribution-NonCommercial } \\
\text { onal License. }\end{array}$ \\
\hline
\end{tabular}

Özet
Amaç: Renal transplant cerrahisinin güven-
liğini artırmak veya postoperatif fonksiyonları
iyileştirmek adına, bazı durumlarda nativ böbrek
nefrektomisi gereksinimi söz konusu olmaktadır.
Prosedürün ise zamanlaması halen tartışmalıdır.
Bu yazımızda, transplant ile eş zamanlı gerçekleş-
tirdiğimiz nativ nefrektomi prosedürlerimizi lite-
ratür eşliğinde sunmayı amaçladık.
Gereç ve Yöntemler: Eylül 2011 ve Şubat
2020 tarihleri arasında Son Dönem Böbrek Yet-
mezliği (SDBY) nedeniyle renal transplantasyon
gerçekleştirilen 245 hastanın verileri retrospektif
olarak incelendi. Transplantasyon ile eşzamanlı
tek taraflı veya bilateral nefrektomi gerçekleştiri-
len hastalar dahil edildi. Hastaların demografik
özellikleri, preoperatif ve postoperatif laboratuar
verileri, primer hastalığı, komorbid hastalık var-
lığı, diyaliz süreleri, vasküler anastomoz süreleri,
cerrahi ve klinik komplikasyonları, hastaneye ya-
tış süreleri ve greft fonksiyonları kaydedildi.
Bulgular: Renal transplantasyona eş zamanlı
ipsilateral veya bilateral nativ nefrektomi gerçek-
leştirilen toplam 12 hasta mevcuttu. Hastaların
SDBY’ye yol açan primer hastalıkları şu şekil-
deydi; 6 (50\%) hasta Polikistik Böbrek Hastalı̆ı̆
(PBH), 5 (41,6\%) hasta vezikoüretral reflü (VUR),
bir (8,3\%) hasta ise böbrek taşı. Üç hastada pos-
toperatif ateş, üç hastada eritrosit replasman te-
davisi, bir hastada ürosepsis ve lenfosel nedenli
perkutan drenaj kateteri gereksinimi kaydedildi.
İki hastada hümoral rejeksiyon ve iki hastada BK
virüs nefropatisi gelişti.

\section{Abstract}

Objective: There is a need for native kidney nephrectomy to increase renal transplant surgery's safety or improve postoperative function in some cases. The timing of the procedure is still controversial. This study aimed to present our native nephrectomy procedures performed simultaneously with the transplantation in light of the literature.

Material and Methods: A retrospective analysis was performed on the data of 245 patients who underwent renal transplantation due to end-stage renal failure (ESRD) between September 2011 and February 2020. Patients who underwent unilateral or bilateral nephrectomy simultaneously with transplantation were included. Demographic characteristics of the patients, preoperative and postoperative laboratory data, primary disease, presence of comorbid diseases, duration of dialysis, duration of vascular anastomosis, surgical and clinical complications, duration of hospital stay, and graft functions were recorded.

Results: 12 patients underwent ipsilateral or bilateral native nephrectomy simultaneously with renal transplantation. The primary diseases of the patients leading to ESRD were as follows; 6 (50\%) patients with Polycystic Kidney Disease (PKD), 5 (41.6\%) patients with vesicoureteral reflux (VUR), one $(8.3 \%)$ patient with kidney stones. Postoperative fever in three patients, erythrocyte replacement therapy in three patients, urosepsis and urinary drainage catheter requirement in one patient due to lymphocele was recorded. Two patients developed humoral rejection, and two patients developed BK virus nephropathy.

Cite As: Karadağ S, Güler AF, Kargı T et al. Simultaneous native nephrectomy with renal transplantation: Our experience and a brief literature review. New J Urol. 2022; 17(1):14-21. DOI: 10.33719/yud.2022;17-1-947050

The study was approved by Ethical Committee of Dr. Sadi Konuk Training and Research Hospital, University of Health Sciences (Approval Number: 2021/191). All research was performed in accordance with relevant guidelines/regulations, and informed consent was obtained from all participants. 
Sonuç: Uygun endikasyon varlığında renal transplantasyon hazırlığındaki hastalarda eş zamanlı nativ nefrektomi güvenli ve efektif bir yöntemdir. Yeterli deneyim ve donanımı olan merkezlerde, nativ nefrektominin renal transplantasyon ile eş zamanlı gerçekleştirilmesi tercih edilebilir.

Anahtar Kelimeler: Böbrek nakli, nefrektomi, bilateral nefrektomi, polikistik böbrek hastalığı, komplikasyonlar.
Conclusion: In the presence of appropriate indications, simultaneous native nephrectomy is a safe and effective method in patients preparing for renal transplantation. In centers with sufficient experience and equipment, it may be preferable to perform native nephrectomy simultaneously with renal transplantation.

Keywords: Kidney transplantation, nephrectomy, bilateral nephrectomy, polycystic kidney disease, complications.

\section{INTRODUCTION}

The gold standard treatment method for end-stage renal failure (ESRD) is renal transplantation (1). In some cases, to increase the safety of transplant surgery or improve postoperative functions, native nephrectomy may be necessary. The most common indications include symptomatic Autosomal Dominant Polycystic Kidney Disease (PKD), reflux nephropathy, staghorn stones, Goodpasture Syndrome, massive proteinuria, and uncontrolled hypertension (2). On the other hand, it is still debated whether the nephrectomy procedure should be planned before or after the transplantation or simultaneously $(1,2)$.

In the 1970s, bilateral nephrectomy was performed before renal transplantation when indicated. However, this method has gradually lost its popularity due to complications such as fluid overload in the anephric phase, congestive heart failure, uremia, anemia due to erythropoietin deficiency, and renal osteodystrophy caused by 1,25-dihydroxycholecalciferol deficiency (3). In the 1980s, prolonged anephric phase complications and multiple surgical interventions were avoided by performing native nephrectomy simultaneously with transplantation. However, it is widely believed that this method increases post-transplant complications (4).

In our clinic, we preferred to perform the nephrectomy procedure simultaneously with the transplantation in patients who required ipsilateral or bilateral native nephrectomy during transplantation preparation. This article aimed to present our simultaneous native nephrectomy experiences in our center, which has a kidney transplant history of nearly ten years.

\section{MATERIAL AND METHODS}

Following the approval (2021/191) obtained from the Ethical Committee of Dr. Sadi Konuk Training and Research Hospital, the data of 245 patients, who underwent renal transplantation due to ESRD between September 2011 and February 2020, were retrospectively analyzed. Patients who underwent unilateral or bilateral nephrectomy simultaneously with transplantation were included. Demographic characteristics of the patients, preoperative and postoperative laboratory data, primary diseases leading to ESRD, presence of comorbid diseases, duration of dialysis, duration of vascular anastomosis, surgical and clinical complications, duration of hospitalization, and graft functions were recorded.

Routine biochemical and microbiological tests were performed in all patients before the operation. In patients whose primary disease was vesicoureteral reflux (VUR), the severity of reflux was evaluated by preoperative voiding cystourethrography (VCUG). Methylprednisolone or anti-thymocyte globulin was used in induction; mycophenolic acid, tacrolimus, and prednisolone were used for maintenance as immunosuppression protocols in patients. The patients were called for a monthly follow-up in the first year in the postoperative period.

The standard transabdominal method with a midline incision was performed in all patients with bilateral nephroureterectomy. After completion of nephrectomies, the transplanted kidney was placed in the iliac fossa, and then the vein and the artery were continuously anastomosed to the external iliac artery and vein using standard methods. The peritoneum was sutured 
and closed on the transplanted kidney, thus preventing the connection of the kidney with the intraperitoneal space. In patients who underwent ipsilateral nephrectomy, the right iliac fossa was reached by making an extraperitoneal curvilinear incision (Gibson), which we use as a standard in kidney transplantation. Then, the incision was extended caudally to reach the native kidney, and an ipsilateral nephrectomy was performed. Subsequently, vascular anastomosis was performed, as we mentioned. A conventional transabdominal method with a midline incision was performed in two patients who have undergone cyst aspiration or decortication in the left kidney concomitant with a right nephrectomy. Ureteroneocystostomy was performed in all patients using the modified Lich-Gregoir technique by placing a routine double-J stent.

\section{RESULTS}

There were 12 patients who underwent ipsilateral or bilateral native nephrectomy simultaneously with renal transplantation. The demographic and perioperative data of the patients are presented in Table 1. The mean age of the patients was $43.5 \pm 12.2$ years, and the mean body mass index (BMI) was calculated as 25.7 $\pm 5 \mathrm{~kg} / \mathrm{m}$ 2. There were 8 male (66.7\%) and 4 female (33.3\%) patients. Preemptive renal transplantation was performed in $8(66.7 \%)$ of the patients. Renal transplantations were performed using open techniques in all patients, and donor nephrectomy procedures were performed from living donors using laparoscopic techniques. All transplanted grafts had single arteries. The primary diseases of the patients leading to ESRD were as follows; 6 (50\%) patients with Polycystic Kidney Disease (PKD), 5 (41.6\%) patients with vesicoureteral reflux (VUR), one (8.3\%) patient with kidney stones. Except for hypertension in two patients, none of the patients had additional comorbidities.

Perioperative complications of the patients, postoperative graft status, changes in preoperative and postoperative creatinine levels up to the first year are presented in Table 2. Bilateral native nephroureterectomy was performed simultaneously with transplantation in all patients with VUR in the etiology. Severe VUR decision in these patients was made with the detection of grade 4-5 reflux in VCUG. The aim of native nephrectomies in these patients was to prevent recurrent urinary tract infections and eliminate potential infection sources. Simultaneous right native nephrectomy was performed in patients whose primary disease was PKD. The aim was to reduce the risk of complications such as recurrent urinary tract infections and bleeding, reduce increased intra-abdominal pressure due to the size of the native kidney, and make room for the graft kidney. At the same time, hemorrhagic cyst aspiration was performed in the left native kidney in one of these patients, and cyst decortication was performed in the left native kidney in another one. In cases with relatively large cysts, we aspirated the cysts. Simultaneous right native nephrectomy was performed in the patient whose etiology was urolithiasis due to recurrent urinary tract infections and the presence of a $6 \mathrm{~mm}$ calculus in the lower pole. The mean duration of operation was $269.1 \pm 37.1$ minutes, the mean amount of bleeding was $233.3 \pm 83.8 \mathrm{ml}$, the mean duration of arterial anastomosis was $10.9 \pm 3$ minutes, and the mean duration of venous anastomosis was $15.4 \pm 5.4$ minutes. The mean duration of hospital stay was $9.5 \pm 6.1$ days.

Erythrocyte replacement therapy (ERT) was required during the postoperative follow-up of the three patients who underwent concurrent right nephrectomy due to PKD. In one of these patients (Patient 4), coronary angiography due to acute coronary syndrome was performed on the third postoperative day, and a cardiac stent was placed. None of the ERTs were performed due to acute gross hemoglobin decrease in the early postoperative period, and their indication was to treat the postoperative anemia. Postoperative fever developed in two patients who underwent bilateral nephroureterectomy and one patient who underwent right nephrectomy. In one of these patients (Patient 10), the infective process progressed to urosepsis, and the clinical condition was controlled with supportive and antibiotic therapy. However, in the imaging performed in this patient, a lymphocele was detected with a diameter of $10 \mathrm{~cm}$ adjacent to the graft kidney, and a drainage catheter was required to be placed by interventional radiology. At the same time, the development of humoral rejection was also noted in this patient. 
In one of the patients (Patient 5), creatinine increased, hematuria developed in the early postoperative period, and the biopsy resulted in humoral rejection. The creatinine level decreased with plasmapheresis treatment. In two patients (Patients 3 and 4), graft biopsies, which were performed due to increased creatinine in the late period, result- ed in BK virus nephropathy, intravenous immunoglobulin therapies were administered to these patients due to the development of side effects against cidofovir.

None of the patients developed wound infections and long-term incisional hernia. The native kidney nephrectomy pathologies of all patients were benign.

Table 1. Preoperative and intraoperative data

\begin{tabular}{|c|c|c|c|c|c|c|c|c|c|c|}
\hline Patient & Age & Gender & BMI & Etiology & Operation & $\begin{array}{l}\text { Duration } \\
\text { (min) }\end{array}$ & Incision & $\begin{array}{l}\text { Bleeding } \\
\text { Amount } \\
(\mathrm{ml})\end{array}$ & $\begin{array}{l}\text { Arterial } \\
\text { Anastomosis } \\
\text { Time (min) }\end{array}$ & $\begin{array}{l}\text { Vein } \\
\text { Anastomosis } \\
\text { Time (min) }\end{array}$ \\
\hline 1 & 48 & M & 24,2 & PKD & $\begin{array}{l}\text { Right } \\
\text { nephrectomy } \\
\text { Left cyst } \\
\text { aspiration }\end{array}$ & 345 & Midline & 120 & 15 & 17 \\
\hline 2 & 49 & $\mathrm{~F}$ & 23,4 & PKD & $\begin{array}{l}\text { Right } \\
\text { nephrectomy }\end{array}$ & 235 & Gibson & 160 & 14 & 15 \\
\hline 3 & 56 & $\mathrm{~F}$ & 26,7 & PKD & $\begin{array}{l}\text { Right } \\
\text { nephrectomy }\end{array}$ & 265 & Gibson & 250 & 10 & 16 \\
\hline 4 & 59 & M & 25,7 & PKD & $\begin{array}{l}\text { Right } \\
\text { nephrectomy }\end{array}$ & 270 & Gibson & 340 & 9 & 12 \\
\hline 5 & 56 & $\mathrm{~F}$ & 25,2 & PKD & $\begin{array}{l}\text { Right } \\
\text { nephrectomy }\end{array}$ & 270 & Gibson & 350 & 8 & 15 \\
\hline 6 & 37 & M & 25,4 & VUR & $\begin{array}{l}\text { Bilateral } \\
\text { nephroureterectomy }\end{array}$ & 210 & Midline & 120 & 12 & 17 \\
\hline 7 & 29 & $\mathrm{M}$ & 17,9 & VUR & $\begin{array}{l}\text { Bilateral } \\
\text { nephroureterectomy }\end{array}$ & 270 & Midline & 250 & 13 & 13 \\
\hline 8 & 29 & M & 29,4 & VUR & $\begin{array}{l}\text { Bilateral } \\
\text { nephroureterectomy }\end{array}$ & 310 & Midline & 200 & 12 & 28 \\
\hline 9 & 29 & $\mathrm{~F}$ & 19,7 & VUR & $\begin{array}{l}\text { Bilateral } \\
\text { nephroureterectomy }\end{array}$ & 235 & Midline & 350 & 9 & 10 \\
\hline 10 & 29 & M & 21,1 & VUR & $\begin{array}{l}\text { Bilateral } \\
\text { nephroureterectomy }\end{array}$ & 300 & Midline & 250 & 15 & 22 \\
\hline 11 & 56 & M & 26,7 & $\begin{array}{l}\text { Urolithiasis } \\
\text { Chronic } \\
\text { Pyelonephritis }\end{array}$ & $\begin{array}{l}\text { Right } \\
\text { nephrectomy }\end{array}$ & 280 & Gibson & 160 & 6 & 8 \\
\hline 12 & 45 & $\mathrm{M}$ & 23,6 & PKD & $\begin{array}{l}\text { Right } \\
\text { nephrectomy } \\
\text { Left cyst } \\
\text { decortication }\end{array}$ & 240 & Midline & 250 & 8 & 12 \\
\hline
\end{tabular}

BMI: Body mass index PKD: Polycystic Kidney Disease VUR: Vesicoureteral reflux 


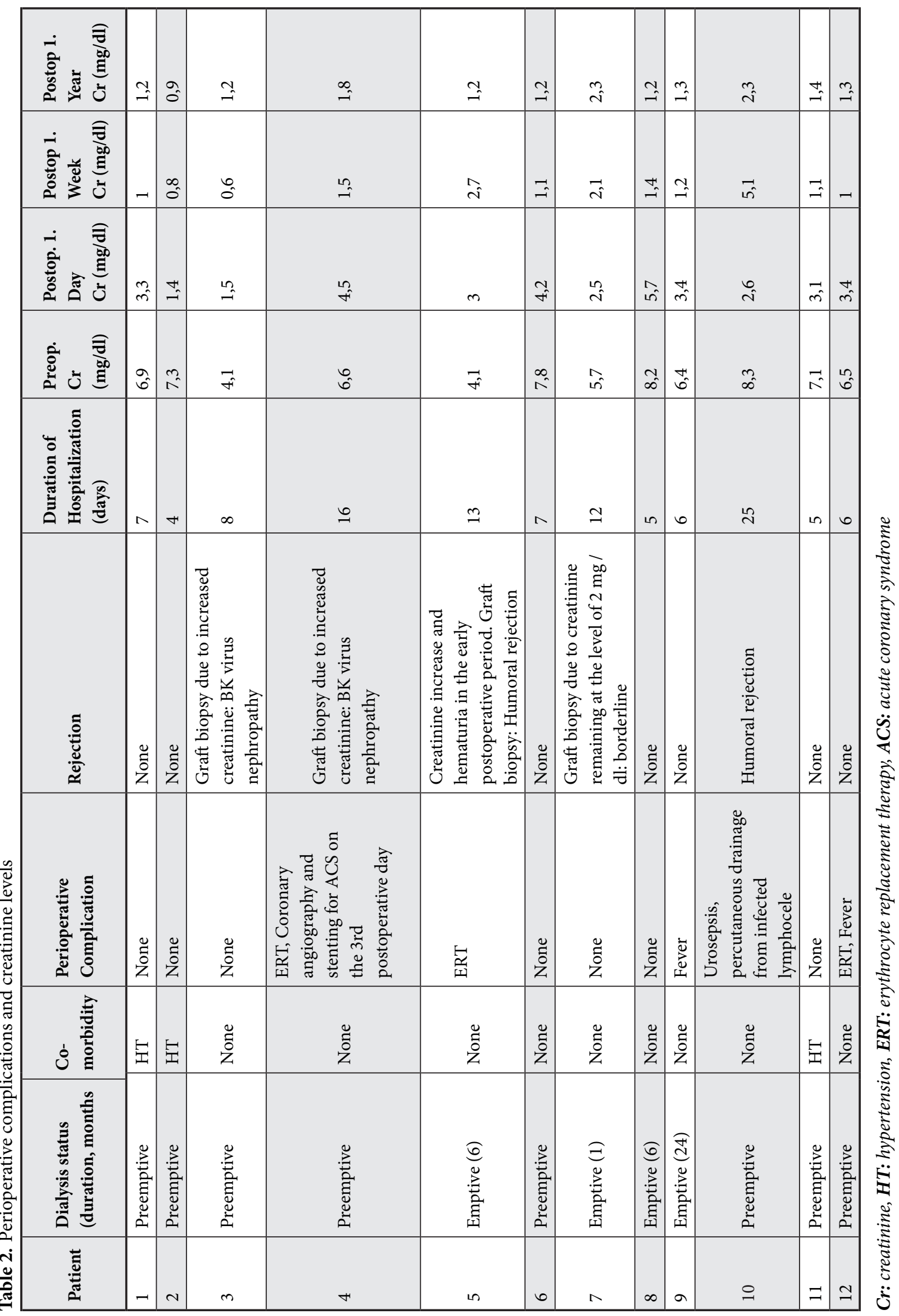




\section{DISCUSSION}

Native nephrectomy is one of the most frequently used auxiliary surgical procedures in patients scheduled for renal transplantation (5). The most common indication for nephrectomy in these patients is PKD (4). PKD is an inherited and progressive kidney disease in which renal functions are impaired by compression of the normal parenchyma by multiple bilateral cysts, resulting in ESRD by $50 \%$ during adulthood. In $5-10 \%$ of all ESRD, the primary disease is PKD (6). Cystic kidneys cause symptoms such as abdominal pain, abdominal swelling, and early satiety with the effect of local compression. They can lead to complications such as cyst rupture, hemorrhage, and urinary tract infections as far as sepsis. The management of symptoms and other abdominal complications of PKD is complex, and its surgery poses technical challenges. Controversy continues about the indications for surgery, surgical approach, and timing (7). The reasons for nephrectomy in this disease include urinary tract infections, hematuria, flank pain, cancer risk, respiratory problems due to excessively enlarged kidneys, gastroesophageal reflux, signs of increased intra-abdominal pressure, and the need to provide more space for the graft kidney ( 1 , $4,8)$. In half of our patients, who underwent concurrent native nephrectomy, the primary cause was PKD, and ipsilateral nephrectomy was performed mostly with the indication of providing space for the graft.

Studies on patients with PKD have demonstrated that concurrent native nephrectomy improves the quality of life in patients without increasing mortality and morbidity $(1,9)$. Drognitz et al. argued that ipsilateral nephrectomy could be performed safely with a Gibson incision within the retroperitoneal approach without impairing patient and graft functions (1). On the contrary, in the study by Dinckan et al., more complications were observed in patients who underwent bilateral nephrectomy for PKD than patients who underwent nephrectomy due to other reasons (8). In this study, transplantation and simultaneous nephrectomy procedures were performed using a transabdominal approach. This change in complication rates may have stemmed from the differences in the surgical approach, such as the retroperitoneal approach with the Gibson incision or the transabdominal approach. The complication rate increases significantly with the transabdominal approach. With the transabdominal method using midline incision may cause delays in the recovery of postoperative enteral dysfunctions (10).

Interestingly, in the study of Dinkcan et al., fewer complications developed in patients without PKD who underwent bilateral nephrectomy with the transabdominal method, compared to the patients with PKD, although the same surgical technique was used (8). The authors attribute this result to the larger dissection requirement due to the larger size of the cystic kidneys, adhesions to surrounding organs, and the rupture of infected cysts. This finding was also confirmed in the study conducted by Song et al. (11). Longer durations of operation, more frequent need for blood transfusions, and neighboring organ injuries were reported in patients who underwent concomitant bilateral native nephrectomy, compared to the patients who did not undergo native nephrectomy. Nonetheless, better blood pressure control was achieved in the long term in these patients, and the possibility of recurrent infections was reduced. Fuller et al. also supported this and reported that concurrent native nephrectomy was safe and effective and did not affect the graft results in their study in which they compared the results of pre-, simultaneous and post-transplant native nephrectomy in PKD patients (12).

Renal transplantation and other concurrent native nephrectomy indications include uncontrolled hypertension, Goodpasture syndrome, chronic pyelonephritis, urolithiasis, heavy proteinuria, structural abnormalities in the urinary tract that increase susceptibility to infections, and severe VUR $(1,2)$. VUR may cause problems in transplantation candidates such as post-transplant recurrent infections and bleed; therefore, it requires ureteral reimplantation and nephroureterectomy (13). We performed simultaneous bilateral nephroureterectomy in five patients due to VUR.

The timing of the procedure is still controversial. Today, instead of performing native nephrectomy before transplantation, the simultaneous procedure comes to the fore due to complications such as hyperkalemia, congestive heart failure, osteodystrophy, and 
anemia in the anephric period $(14,15)$. Patients undergoing nephrectomy simultaneously with transplantation have significantly higher hemoglobin levels at the time of transplant due to erythropoietin produced from native kidneys, compared to patients who have previously undergone nephrectomy (15). In addition, the fact that these patients have residual diuresis makes the fluid restriction process more manageable in patients undergoing dialysis treatment (15). Moreover, in the case of a native nephrectomy before transplantation, a blood transfusion may be required during or after the nephrectomy procedure, which may cause sensitization that may complicate the scheduled transplantation (16).

The sandwich technique and unilateral nephrectomy were tested in the past to prevent the risk of an anephric phase. Nephrectomy was performed before transplantation to the kidney, which was more damaged, and nephrectomy of the contralateral kidney was performed after the transplantation; hence, there was no need for intraperitoneal access and additional simultaneous operations $(17,18)$. Nonetheless, the most important disadvantage of this technique was the morbidity brought by the three consecutive surgical requirements (10).

Simultaneous native nephrectomy does not appear to cause an additional burden in terms of surgical complications or allograft function $(8,15,19-21)$. However, the situation is slightly different for bilateral nephrectomy. Simultaneous bilateral nephrectomy is beneficial in PKD for reasons such as bleeding, recurrent infection, and cancer after the transplantation. Nonetheless, simultaneous bilateral native nephrectomy is associated with a higher rate of perioperative complications compared to renal transplantation alone, albeit being a tolerable procedure with good patient satisfaction (2, $8,21)$. Routine nephrectomy before the transplantation is no longer recommended unless there is a clear indication of bleeding, infection, or suspected malignancy $(20,22,23)$.

The most important limitation of our study was that the number of cases was too small to make an inference, and there were no comparison groups. In addition, another important limitation was its retrospective design.

\section{CONCLUSION}

In the presence of appropriate indications, simultaneous native nephrectomy is a safe and effective method in patients preparing for renal transplantation. Simultaneous native nephrectomy procedures performed in our clinic resulted in acceptable rates of complication. In centers with sufficient experience and equipment, it may be preferable to perform native nephrectomy simultaneously with renal transplantation.

\section{Conflict of interest}

The authors declare to have no conflicts of interest.

\section{Financial Disclosure}

The authors declared that this study has received no financial support.

\section{Informed Consent}

Informed consent was obtained from all individual participants included in the study.

\section{Ethical Approval}

The study was approved by Ethical Committee of Dr. Sadi Konuk Training and Research Hospital, University of Health Sciences (Approval Number: 2021/191) and written informed consent was received from all participants. The study protocol conformed to the ethical guidelines of the Helsinki Declaration.

\section{Author Contributions}

Conception and design; SK, TK, ME, DNÖ, Data acquisition; HP, İE, OÖ, Data analysis and interpretation; SK, AFG, AH, ME, DNÖ, Drafting the manuscript; SK, TK, AH, İE, DNÖ, OÖ, Critical revision of the manuscript for scientific and factual content; AFG, AH, DNÖ, Statistical analysis; AFG, HP, ME, Supervision; SK, TK, İE, DNÖ, OÖ.

\section{REFERENCES}

1. Drognitz O, Kirste G, Schramm I, et al. Kidney transplantation with concomitant unilateral nephrectomy: a matched-pair analysis on complications and outcome. Transplantation, 2006; 81(6):874-880.

2. Ismail HR, Flechner SM, Kaouk JH, et al. Simultaneous vs. sequential laparoscopic bilateral native nephrecto- 
my and renal transplantation. Transplantation, 2005; 80(8):1124-1127.

3. Glassman DT, Nipkow L, Bartlett ST, et al. Bilateral nephrectomy with concomitant renal graft transplantation for autosomal dominant polycystic kidney disease. J Urol, 2000; 164(3 Pt 1):661-664.

4. Krol R, Ziaja J, Cierniak T, et al. Simultaneous transabdominal bilateral nephrectomy in potential kidney transplant recipients. Transplant Proc, 2006; 38(1):28-30.

5. Shoma AM, Eraky I, El-Kappany HA. Pretransplant native nephrectomy in patients with end-stage renal failure: assessment of the role of laparoscopy. Urology, 2003; 61(5):915-920.

6. Torres VE, Harris PC, Pirson Y. Autosomal dominant polycystic kidney disease. Lancet. 2007; 369(9569):12871301.

7. Dengu F, Azhar B, Patel S, et al. Bilateral Nephrectomy for Autosomal Dominant Polycystic Kidney Disease and Timing of Kidney Transplant: A Review of the Technical Advances in Surgical Management of Autosomal Dominant Polycystic Disease. Exp Clin Transplant. 2015; 13(3):209-213.

8. Dinckan A, Kocak H, Tekin A, et al. Concurrent unilateral or bilateral native nephrectomy in kidney transplant recipients. Ann Transplant. 2013; 18:697-704.

9. Kramer A, Sausville J, Haririan A, et al. Simultaneous bilateral native nephrectomy and living donor renal transplantation are successful for polycystic kidney disease: the University of Maryland experience. J Urol, 2009; 181(2):724-728.

10. Midtvedt K, Hartmann A, Bentdal O, et al. Bilateral nephrectomy simultaneously with renal allografting does not alleviate hypertension 3 months following living-donor transplantation. Nephrol Dial Transplant. 1996; 11(10): 2045-2049.

11. Song WL, Zheng JM, Mo CB, et al. Kidney transplant for autosomal dominant polycystic kidney disease: the superiority of concurrent bilateral nephrectomy. Urol Int. 2011; 87(1): 54-58.

12. Fuller TF, Brennan TV, Feng S, et al. End stage polycystic kidney disease: indications and timing of native nephrectomy relative to kidney transplantation. J Urol, 2005; 174(6): 2284-2288.
13. Aygun C, Ozer C, Dirim A et al. Renal transplantation experience following endoscopic treatment of vesicoureteral reflux. Transplant Proc, 2004; 36(1): 68-70.

14. Mitchell TS, Halasz NA, Gittes RF. Renal transplantation: selective preliminary bilateral nephrectomy. J Urol, 1973; 109(5): 796-801.

15. Veroux M, Zerbo D, Basile G, et al. Simultaneous Native Nephrectomy and Kidney Transplantation in Patients With Autosomal Dominant Polycystic Kidney Disease. PLoS One. 2016; 11(6):e0155481.

16. Scornik JC, Bromberg JS, Norman DJ, et al. An update on the impact of pre-transplant transfusions and allosensitization on time to renal transplant and on allograft survival. BMC Nephrol 2013; 14:217.

17. Brazda E, Ofner D, Riedmann B, et al. The effect of nephrectomy on the outcome of renal transplantation in patients with polycystic kidney disease. Ann Transplant, 1996; 1(2):15-18.

18. Cassuto-Viguier E, Quintens H, Chevallier D, et al. Transplantation and nephrectomy in autosomal dominant polycystic disease. Clin Nephrol. 1991; 36(2):105106.

19. Kim JH, Chae SY, Bae HJ, et al. Clinical Outcome of Simultaneous Native Nephrectomy and Kidney Transplantation in Patients With Autosomal Dominant Polycystic Kidney Disease. Transplant Proc. 2016; 48(3):840-843.

20. Kirkman MA, van Dellen D, Mehra S, et al. Native nephrectomy for autosomal dominant polycystic kidney disease: before or after kidney transplantation? BJU Int. 2010; 4:590-594.

21. Lucas SM, Mofunanya TC, Goggins WC, et al. Staged nephrectomy versus bilateral laparoscopic nephrectomy in patient with autosomal dominant polycystic kidney disease. J Urol 2010; 184(5):2054-2059.

22. European Renal best practice transplantation guideline development group. ERBP guideline on the management and evaluation of the kidney donor and recipient. Nephrol Dial Transplant. 2013; 28(suppl.2);ii1-ii71.

23. Akoh JA. Current management of autosomal dominant polycystic kidney disease. World J Nephrol 2015; $4(4): 468-479$. 